Article

\title{
Charting Putin's Shifting Populism in the Russian Media from 2000 to 2020
}

\author{
Tina Burrett \\ Faculty of Liberal Arts, Sophia University, 102-8554 Tokyo, Japan; E-Mail: tburrett@sophia.ac.jp
}

Submitted: 18 October 2019 | Accepted: 16 January 2020 | Published: 5 March 2020

\begin{abstract}
This article analyses the changing themes of Vladimir Putin's populist messaging during his almost 20 years at the apex of Russian politics. To reveal shifts in Putin's populist rhetoric, the article examines Russian media framing of his four presidential-election campaigns and of Russia's relations with China and the United States (U.S.). Public opinion data is used to assess the impact of Putin's populist propaganda. The article begins by assessing to what degree Putin can be considered a populist politician, concluding that while his rhetoric is populist his rule is largely not. The article further finds that Putin has maintained his populist appeal by turning his ire from domestic economic elites to international political enemies, specifically by positioning himself as the main challenger to U.S. hegemony in the global system. Putin's control of the Russian media, co-opting of opposition populist causes and geopolitical victories in Syria and Crimea have helped him maintain his populist connection with Russian voters. But, the article concludes, growing access to anti-Kremlin online media, the pain of economic sanctions, botched social welfare reforms, and the presence of effective opposition movements are causing Putin's populism to lose its lustre.
\end{abstract}

\section{Keywords}

international relations; populism; Russia; Russian media; Russian politics; Vladimir Putin

Issue

This article is part of the issue "Leadership, Populism and Power" edited by Cristine de Clercy (Western University, Canada).

(C) 2020 by the author; licensee Cogitatio (Lisbon, Portugal). This article is licensed under a Creative Commons Attribution 4.0 International License (CC BY).

\section{Introduction}

Almost two-decades before Donald Trump, Vladimir Putin won power in Russia by promising to 'make Russia great again.' A faceless functionary until his surprise appointment as President Yeltsin's prime minister in August 1999, Putin used his obscurity to fashion a populist image as a man of the people. Earthy-toned pledges to 'wipe out' Chechen terrorists, crackdown on unruly oligarchs and to restore Russia's international prestige won Putin the presidency in March 2000. During his first presidential term, Putin's jailing and exile of media moguls and other tycoons helped remove his wealthy political opponents, while cementing his anti-establishment credentials with ordinary Russians (Burrett, 2011).

By the time Putin sought re-election for a third presidential term in 2012, however, he had become a victim of his own success. After serving at the apex of Russian politics for 12 years, Putin was undeniably the establishment candidate. To renew his populist appeal, Putin turned his anger from domestic economic elites to international political enemies and their alleged fifth-column provocateurs, positioning himself as the main challenger to the Western-dominated global order (Burrett, 2019). To help Putin reconnect with voters ahead of presidential elections, the Kremlin also began promoting a new narrative about Russia as Europe's last bastion of traditional values, defined as moral conservatism and Orthodox Christianity (Tolz \& Harding, 2015, p. 476). Furthermore, to counter the emergence of genuine public opposition protests in 2011-2012, Putin's government introduced legislation aimed at reinvigorating Russian citizens' sense of patriotism, as well as sanctioning an array of patriotic organisations targeting Russia's perceived domestic enemies (Baunov, 2017).

Although Putin has clearly borrowed from the populist playbook to win and retain power over the past 20 years, this article argues that he has also eschewed many of the tactics deployed by populist leaders in other parts of the world. Putin, for example, 
has largely rejected the anti-immigration, Islamophobic, ethno-nationalism of many European right-wing populists, instead championing Russia's multi-ethnic character as a national strength. Putin's rhetoric, meanwhile, frames close relations with Central Asia, China, and other rising powers as essential to the country's great-power status (Hutchings \& Tolz, 2015, p. 27). Unlike populist presidents Donald Trump or Recep Tayyip Erdoğan, Putin has sought to strengthen the state's institutional foundations and is at pains to appear to be following established legal procedures, even if in reality he frequently breaks the rules (Baunov, 2017). Putin's government maintains its legitimacy through institutions as well as through popular public support, aiming to make other state institutions subservient to the presidency rather than to destroy them (Sakwa, 2012).

This article has three parts. The first part analyses to what extent Vladimir Putin can be described as a populist. It compares Putin's leadership to academic definitions of populism, arguing that while elements of Putin's political approach conform to these definitions, in other ways it contradicts them. The second part of the article charts how the themes of Putin's populist messaging have changed over his four terms as president. To investigate Putin's changing rhetoric, the article analyses the Kremlin-sanctioned narratives promoted by Russianstate controlled media. Television has played a central role in disseminating official discourses in Russia since Putin first became president in 2000 (Burrett, 2011). At its core, populism is an ideology pitting a virtuous people against a corrupt elite (Mudde, 2007). Analysis in this article therefore focuses on Russian-media framing of domestic and international elites. Furthermore, since populist movements generally seek to impose the will of the people on 'others,' the framing of 'otherness' by the Russian media is also explored (Morelock, 2018, p. XIV). The article demonstrates that in light of public protests that followed the announcement that Putin would seek a third presidential term in 2012, official discourses changed substantially. Major shifts included a change in focus from domestic to international 'enemies' and a growing concentration on the West as Russia's main other. At the same time, the article finds that media reporting on China became more positive. These arguments will be elaborated by comparing Russian television framing of Putin's earlier (2000 and 2004) and later (2012 and 2018) presidential election campaigns. To assess the Russian media's representation of 'otherness,' the article also examines changing coverage of Russia's relations with the United States (U.S.) and China over the course of Putin's four presidencies. Drawing on media discourse theory, news reports are analysed qualitatively for changes in framing (emphasizing or excluding specific facts to promote particular definitions and interpretations), narrative, rhetorical strategy, and visual imagery, all of which can influence the way audiences interpret events (Hansen, Cottle, Negrine, \& Newbold, 1998). The final section of the article analyses the dura- bility of Putin's populism. It argues that Putin's control of the Russian media, co-opting of opposition populist causes and geopolitical victories in Syria and Crimea have helped him maintain his populist connection with Russian voters, despite presiding over an enduringly kleptocratic state. It is further argued, however, that growing access to anti-Kremlin online media, the pain of economic sanctions, botched social welfare reforms, and the presence of effective opposition movements are causing Putin's populism to lose its appeal. The article's conclusion returns to the question of whether Putin can be classified as a populist, arguing that his leadership fits most closely with discursive descriptions of populism and that the Russian president has become less populist and more nationalist over the course of his long tenure (de la Torre, 2007).

\section{Is Putin a Populist?}

The definition of populism is hotly contested among social scientists. Some scholars use the term exclusively to describe radical-right ethno-nationalist parties, such as Fidesz in Hungary, while others also apply the term to anti-austerity leftist parties, such as Spain's Podemos or Syriza in Greece (Ostiguy \& Roberts, 2016). Some scholars include social movements as well as political parties in definitions of populism, for example the Occupy Wall Street or Tea Party movements in the U.S. (Williamson, Skocpol, \& Coggin, 2011). Nevertheless, most scholars concur that across its diverse manifestations, populism expresses a division between 'the people,' however defined, and some type of elite (Mudde \& Rovira Kaltwasser, 2012, p. 8). There is a general consensus that populists present themselves as the voice of the silent majority, whose interests are being ignored by the establishment. Many definitions recognise that populism does not map onto a conventional left-right axis of political competition (Ostiguy \& Roberts, 2016, p. 26). Indeed, populist leaders may draw support simultaneously from both sides of the left-right spectrum.

From Rodrigo Duterte to Narendra Modi, populism is often characterised as guided by a strong, charismatic personality (Albertazzi \& McDonnell, 2008, p. 7). Yet not all manifestations of populism are led by charismatic figures, as demonstrated by leaderless populist movements like the Arab Spring (O'Brien, 2015, p. 337). Furthermore, when scholars identify a populist leader as 'charismatic' this impression is usually based on how leaders present themselves (as saviours of the people) or how they perform (rousing political speeches) rather than on how their followers perceive them (Albertazzi \& McDonnell, 2008 , p. 27). Max Weber, who coined the concept of charisma, however, specified that what is important is how followers regard their leaders (Weber, 1978, p. 242). It is not what the leader is, but what the people see the leader as being that counts in generating the charismatic relationship. Weber further theorised that particularly at times of crisis, 'the people' would come to see some- 
body as a 'saviour,' ascribing to them a charismatic quality, whether actual or presumed (Weber, 1978, p. 295).

Vladimir Putin first came to national prominence in Russia in turbulent times. Renewed conflict in Chechnya in August 1999 prompted President Yeltsin to promote the little-known Putin-then head of the Security Council-to prime minister. In this role, Putin capitalised on the patriotic emotions engendered by the Chechen conflict. Jingoistic coverage of the war on state-owned television helped Putin build his public image as a decisive leader (Burrett, 2011). Prior to his appointment as premier, Putin was a relatively unknown figure outside the political elite. When he took office as prime minister, only two percent of voters identified him as their choice to replace Yeltsin (Russian Public Opinion Research Center, 1999). But Putin's obscurity was an advantage, allowing him to create his public persona from scratch. Television coverage showing Putin planning tough action against Chechen terrorists, inspecting troops and taking part in martial arts competitions transformed him from a bland security officer into the strong leader Russians desired. Basing his 2000 presidential campaign on the ambiguous slogan 'Great Russia,' Putin was able to satisfy the competing interests of diverse domestic constituencies. In the 2000 and 2004 presidential elections, Putin won by a wide margin, like many populists, cutting across left-right cleavages to gain support from neoliberals, post-Soviet communists and nationalists alike (Burrett, 2019).

Despite strong xenophobia in Russian public sentiments, as far as it is consistent, Putin's nationalist rhetoric is relatively moderate. Unlike populist leaders in many parts of Europe, Putin's nationalism has mainly emphasised citizenship rather than ethnic heritage as the basis for inclusion in a multi-ethnic Russian nation. Putin's nationalist rhetoric is largely aimed at controlling rather than mobilising xenophobic nationalism (Krastev, 2007). This does not preclude, however, the selective deployment of ethnic nationalism for electoral and legitimation purposes (Tolz, 2017). In response to the public protests that followed his re-election in 2012, Putin turned to ethno-nationalism to stabilise support for his administration. Since opinion polls show widespread xenophobia in Russia, including ethno-racial definitions of national identity in the official discourses disseminated by the Russian media allowed Putin to show his concern for public grievances (Levada Center, 2012). But following Russia's annexation of Crimea in March 2014, narratives stigmatising Russia's ethnic or religious minorities were again dropped. Putin could hardly accuse Ukraine's new government of 'fascist' discrimination against its Russian diaspora while encouraging ethnoracial representations of the Russian nation at home (Tolz, 2017, p. 753).

In appealing to nationalist sentiments, Putin has sought to mobilise society behind the reestablishment of order after the economic and political turbulence of the 1990s (Laruelle, 2009). The state that Putin inherited from Yeltsin in 2000 was weak and fragmented (Ruble, Koehn, \& Popson, 2001). Regional governors established personal fiefdoms that overtly rebuffed central authority while several national republics talked of secession. Russia's oligarchs plundered the nation's wealth with little respect for the rule of law (Sakwa, 2012, p. 10). By successfully mobilizing themes that were previously the reserve of ultra-nationalists and using them to promote a state-building nationalism that has stabilized Russian society, Putin is at odds with the majority of populists. More often, populist leaders show scant regard for institution building, beyond creating or co-opting political parties that act as a personal vehicle for winning elections (Mudde, 2007). In using nationalism to strengthen the state, Putin has more in common with nineteenth century state-building nationalists in Britain and Japan than with many contemporary populists (Hechter, 2001).

Scholars argue that populist leaders establish a particular type of polity, what Peter Mair has termed 'populist democracy.' Under this system, charismatic leaders claiming to embody the 'will of the people' reject institutional constraints on their power (Mair, 2002, p. 90). In the populist playbook, defying convention and even breaking the law are celebrated as acts of subversion and as evidence that the leader will stop at nothing to serve the people (Fieschi, 2019). Populists thus tend to distain liberal and deliberative forms of democracy. Moreover, many populist leaders also undermine electoral forms of democracy by casting their opponents as illegitimate actors (Mudde \& Rovira Kaltwasster, 2014, p. 384). Donald Trump is a good example of a populist leader prone to labelling his critics as criminals or fakes. But although Putin has undoubtedly trampled on democratic norms and emasculated liberal institution in Russia, he has gone to great lengths to appear to be following legal procedures (Burrett, 2011). Putin, for example, behaves differently from many populists by refusing to comment on court cases involving his political adversaries. Yet at the same time, in using his influence over Russia's courts to harass his opponents, Putin's actions are more typical of a populist.

Populists in power invariably seek constitutional revisions to strengthen the executive, while weakening checks and balances (Pappas, 2019, p. 73). Putin has not radically altered Russia's constitution, perhaps because it already granted a dominant role to the president, who has the right to issue decrees, dissolve parliament and veto legislation (Huskey, 1999). Russia's existing constitution gave Putin all the tools he needed to build a vertical power structure. In 2004, without constitutional amendments, Putin eliminated direct gubernational elections, giving himself the power to appoint Russia's 89 regional leaders. Henceforth, regional governors were chosen based on their loyalty to the Kremlin (Ferris, 2019). Following demonstrations over alleged parliamentaryelection fraud in 2011, directly-elected regional governors were reinstated in 2012 (Teague, 2014). When selecting candidates to run for regional governorships, 
Putin has drawn on a new generation of technocrats, giving them responsibility for delivering his 12 'national projects,' that include increasing employment, raising living standards and improving infrastructure. Whereas Putin formerly drew on his personal network of fellow former security officers, his recent political appointees have been chosen for their professional experience. By promoting a new generation and granting them a degree of autonomy, Putin is attempting to transform Russia's system of governance that is too dependent on him personally (Hille \& Foy, 2018). In building an overly centralised system predicated on his personal leadership, Putin's actions are in line with populists such as Hugo Chávez or Viktor Orbán (Pappas, 2019, p. 72). But in now seeking to depersonalise and decentral power-albeit to a limited degree-Putin's actions run counter to the populist norm (Müller, 2017).

More in keeping with the populist standard, Putin was behind constitutional amendments that extended presidential terms from four to six years from 2012. But in contradiction to this, when his constitutionally limited two-consecutive terms as president were over in 2008, Putin did not seek to extend his tenure by referenda or ad hoc laws like many populists (Pappas, 2019). Rather, Putin took a four-year interlude from the presidency, serving as prime minister to his protégé Dmitry Medvedev from 2008-2012. Putin's moves vis-à-vis Russia's constitution both confirm and confound expectations of populist rule. His decision to take a hiatus from the presidency may have been cosmetic, but appearances are important. Along with public support, the appearance of institutionalised procedures is the foundation of his legitimacy (Baunov, 2017).

Although Putin largely seeks to govern through institutions, his authority over those institutions rests on his direct, unmediated support from ordinary Russians. In seeking to connect directly with voters on a personalistic level, Putin follows an approach common among populist leaders (Mudde \& Rovira Kaltwasser, 2012, p. 378). Although the United Russia Party was created as a vehicle to support Putin's legislative agenda in the Russian parliament, in three out of four presidential elections he has stood as an independent rather than on the party ticket.

Again, in common with many populists, Putin frequently employs crude language and displays of machismo to show he is a man of the people who will protect the nation (Sperling, 2016). The abundance of manly Putin-images presented by the Russian media are internationally notorious: bare-chested outdoor man, fighter pilot and, most theatrically, the tamer of Siberian tigers (Schuler, 2015, p. 137). The public first heard Putin's coarse language in September 1999 when he vowed revenge after Russia was hit with several deadly terrorist bombings. Putin didn't hold back: 'We'll catch them in the toilet, we will wipe them out in the sh*thouse,' he said (Dougherty, 2015). Since then, Putin has regularly sprinkled his statements with vulgarisms. In response to a hostile question from a journalist at a Brussels summit in 2002, Putin bizarrely offered his questioner a circumcision. The following year, Putin raised eyebrows again when he criticised Russia's oligarchs saying, 'you must always obey the law, not just when they've got you by the balls' (Strauss, 2003).

Putin's populist gestures have helped him solidify support among Russian citizens. During his first two presidential terms, his approval ratings averaged approximately 70 percent (Levada Center, 2019a). But Putin's public support is predicated more on the provision of socially popular measures than on a genuine emotional connection with voters. Attempts to reform social benefits in 2004 and to raise Russia's retirement age in 2018 resulted in public protests and a plunge in Putin's approval ratings (Myers, 2005; Volkov, 2018). In both cases, Putin watered down his proposals in response to public pressure. Unlike populist leaders in other countries who aim to mobilise and politicise their supporters with what Conaghan and de la Torre (2008) call a 'permanent campaign,' Putin's governing strategy is based on demobilising and depoliticising Russian citizens (Laruelle, 2013, p. 4). But demobilisation is not necessarily counter to populism. Many populist leaders substitute 'rule by the people' with 'rule for the people,' with the leader supposedly embodying the people's will. In this sense, populism without participation is not an incoherent proposition. Populists, such as Silvio Berlusconi or Viktor Orbán, often adopt a caretaker attitude towards a passive public (Müller, 2016, p. 30).

Putin's transactional rather than emotional connection with his followers suggests only weak evidence of populism. But populism can be viewed as an ordinal rather than nominal category. If conceived as nominal, leaders are either populist or they are not. But if viewed as ordinal, leaders can be located spatially on a scale, with some conforming to more elements of populism than others (Ostiguy, 2017, p. 89). Very few leaders fit all the attributes of populism as outlined by scholars in their varied definitions. Putin may not be a populist in all aspects of his leadership, but this does not mean that certain populist elements are not part of his repertoire.

As well as viewing populism as ordinal, scholars have described different varieties of populism. Three main conceptual approached have emerged defining populism respectively as an ideology, a discursive style and as a form of political motivation. Cas Mudde's (2007) influential ideational approach described populism as a 'a thin centred-ideology' that extols the pure, authentic people in their confrontation with a corrupt elite. Due to its generic worldview, Mudde argues, populism can combine with other more specific ideologies. An alternative approach describes populism as a discursive style. Analysing populism in Latin America, Carlos de la Torre (2007, p. 389) defines populism as a discourse framing politics as a struggle between the people and the oligarchy. Here, populism is not an ideology, but a mode of political expression built around a dichotomy between 'them' and 'us.' In contrast to ideational and discursive 
approaches, some scholars understand populism as a political strategy. This approach focuses on different aspects of political strategy: policy choices, political organizations, and forms of public mobilisation (Madrid, 2008). This article argues that Vladimir Putin conforms most closely to discursive descriptions of populism. As outlined above, Putin's rhetoric is often populist, but his style of governance is largely not. It is further argued that over time, Putin has shifted from populist to more nationalist discourses. The section that follows analyses how the focus of Putin's rhetorical appeals has changed over the course of his four presidential terms.

\section{How Has Putin's Populist Messaging Changed?}

\subsection{From the Oligarchs to Overseas Enemies}

In his campaigns for the Russian presidency in 2000 and 2004, Putin emphasised his firmness in standing up to forces undermining Russia's stability, dignity, and honour (Lambroschini, 2000). In 2000, foremost in Putin's sights were separatists in Chechnya. Yet despite being chosen by Yeltsin and his band of oligarchs as a loyal successor who would preserve crony capitalism and keep them out of jail, Putin also turned his ire on those who had accumulated billions by appropriating state assets. In the aftermath of the 1998 Russian financial crisis that saw living standards plummet, the oligarchs, who had accumulated vast wealth by seizing Russia's rich natural resources, were an easy populist target. At a meeting with the oligarchs a month before the March 2000 presidential election, Putin made it clear that under his leadership the rules of the game would change (Goldman, 2004, p. 36). In his statement-widely reported in the Russian media-Putin told Russia's tycoons that they would no longer be able to flout government regulations or to count on special access to the Kremlin. Putin reiterated the same message in an open letter to voters published in three national newspapers on 25 February 2000, writing:

Our priority is to protect the market against illegal invasion, both by government bureaucrats and by criminals....All economic entities should be in an equal playing field. (Putin, 2000a)

The acting president argued that individuals taking excessive and illegal rents out of the economy 'threaten our very existence' (Putin, 2000a). Putin's attacks on the oligarchs won him supporters among ordinary Russians' struggling to make ends meet, as well as among the country's young entrepreneurs, angry that the growth of their companies was being undermined by the lawlessness of Russia's business climate and its dominance by financial tycoons close to Yeltsin (Thornhill, 2000). As the election drew closer, Putin's attacks against the oligarchs became more explicit. In an interview on Radio Mayak a week before voting, Putin attacked the oligarchs for 'merging power with capital' and spoke of his aspiration to 'liquidate the oligarchs as a class' (Reddaway, 2001, p. 27). As well as condemning the oligarchs collectively, Putin took aim at individual tycoons. In February 2000, he criticised Unified Energy Systems chief executive Anatoly Chubais for presiding over 'an unstable and disorderly mechanism' that would not need to hike electricity prices if the company was better run (Humphreys \& Bivens, 2000).

During the 2000 election campaign, Putin had to tread carefully against the oligarchs, especially those such as Boris Berezovsky and Vladimir Gusinsky whose media holdings were essential in helping him win (Burrett, 2011). But his own meteoric rise taught Putin the power of the media over public opinion. And after his election, the new president concluded that such a powerful tool could not be left in the hands of unruly tycoons. Legal loopholes and their murky financial dealings provided Putin with levers to wrestle their media assets away from the oligarchs. Less than six months after his election victory, prosecutions were launched against Berezovsky and Gusinsky, forcing both into exile (Burrett, 2011). These moves allowed Putin to extend state control over the media, but also to burnish his anti-elite credentials with ordinary Russians.

At the same time as pursuing their oligarchic bosses, Putin also launched an attack against Russia's liberal media elites. Although journalists working for Berezovsky and Gusinsky helped to get Putin elected, they soon turned on the new president over his inept response to the sinking of the Kursk nuclear submarine in August 2000. In an interview on state-owned broadcaster Rossiya, Putin blamed the media for enflaming public passions over the Kursk disaster, stating that:

The people on television, who for ten years were destroying the army and the navy, where people are now dying, are the first among the army's defenders....They want to show the military and political leadership that we need them, that we are on their hook. (Putin, 2000b)

Media coverage criticising Putin over the Kursk disaster and Chechen war was branded as unpatriotic by his administration (Burrett, 2011). But in his propaganda war with Russia's media elites, Putin was the victor. Only four percent of Russians saw his moves to bring Gusinsky and Berezovsky's media holdings under state influence as a clampdown on free speech. Rivalries between oligarchic clans or economic concerns were more widely accepted explanations (Petrova, 2001).

Putin's war with the oligarchs was a central theme of his re-election campaign in 2004. A public opinion survey less than a year before the election found that 84 percent of Russians believed the oligarchs acquired their wealth illegitimately (Naryshkina, 2004). The majority of Russian voters viewed the social and economic influence of major capitalists as negative (Petrova, 2003). To marshal votes for Putin, a high-profile target was needed to demon- 
strate the sincerity of the president's commitment to ending the parasitic relationship between the oligarchs and the state. Mikhail Khodorkovsky, owner of the oil giant Yukos and one of Russia's most successful businessmen, became the obvious choice when he appeared on television accusing Putin of improprieties over the sale of another energy firm Severnaya Neft to state-owned Rosneft. Around the same time, Khodorkovsky signalled his intentions to enter the political arena by donating to Putin's rivals and buying newspaper Moskovskie Novosti (Latynina, 2003). His deep pockets made Khodokovsky a dangerous adversary. In July 2003, Khodorkovsky's deputy Planton Lebedev-along with several other highranking Yukos employees-was arrested for embezzlement. On 25 October, Khodorkovsky himself was arrested at Novosibirsk airport and charged with fraud and tax evasion amounting to billions of dollars. The nature of Khodorkovsky's arrest was deliberately executed to create a television sensation that would elicit maximum support for the move among ordinary Russians. Khodorkovsky could easily have been arrested in Moscow, but the storming of his private plane gave events a filmic quality and provided footage that would remind audiences of his connection to the privatisation bonanza of the 1990s.

An aggressive campaign on state television was used to frame public thinking about Khodorkovsky. Exploiting voters' long-held distrust of the rich, state television portrayed Khodorkovsky as an oligarch who had reached the pinnacle of his wealth through suspicious means (Tavernise, 2003). Putin appeared on television to defend the arrest as purely an attack on corruption. No other interpretation of events was heard on state-owned channels, with journalists covering the story without analysis and likening the affair to the arrest of Enron executives in the U.S. (Burrett, 2011). A public opinion poll conducted at the end of October 2003 found that 52 percent of Russians accepted Putin's explanation that Khodorkovsky had been arrested solely for violating the law-only 11 percent thought the arrest was politically motivated (Smirnov, 2003). Khodorkovsky's arrest allowed Putin to satisfy public demands for action against the oligarchs while also removing a potentially dangerous political opponent.

Khodorkovsky's fate served to deter other oligarchs tempted to meddle in politics. After neutering the old cadre and consolidating his power during his first two terms in office, the biggest obstacle to Putin's return to the presidency for a third term in 2012 was voter apathy. A high turnout was crucial to legitimating his renewed mandate. But after more than a decade at the top and a record of throwing his political opponents in jail, Putin could hardly campaign as a plucky outsider battling an entrenched elite. To suggest the oligarchs were still plundering Russia's wealth would be to admit failure. To rally populist support for Putin in 2012, therefore, the Kremlin shifted its main focus to a different 'enemy': domestic and international forces bent on over- turning Putin's legacy. State-controlled television was used to vilify those who staged public demonstrations against Putin's return. Putin labelled his domestic detractors as a privileged elite. Russia's best-educated citizens were portrayed as traitors, perhaps in the pay of the U.S. (Krastev \& Holmes, 2012, p. 44). This was not the first time that Putin had invoked anti-Americanism or the idea of a 'fifth column.' During the 2005 Orange Revolution, Putin accused the U.S. of funding anti-government NGOs in Ukraine. He did not, however, accuse Western governments of the same provocateur activities in Russia until 2012, when his government introduced legislation requiring all NGOs receiving overseas funding to register as foreign agents (Elder, 2013). In February 2007, Putin made a powerful speech at the Munich Security Conference accusing Washington of 'forcing its will on the world' and of undermining global security (Yasmann, 2007). But although there are examples of Putin citing external enemies earlier in his presidency, it is not until 2012 that this became a consistent feature of his rhetoric. The subsequent Ukraine crisis from February 2014 gave Putin the perfect opportunity to further solidify nationalist and anti-Western sentiments as the main base of support for his leadership. In a speech in January 2015, for example, Putin asserted that proRussian separatists in Eastern Ukraine were not just fighting the Ukrainian army but also a NATO-sponsored 'foreign legion' (Sperling, 2016, p. 17). Putin's Ukraine strategy worked as intended. Thanks to his role as the embodiment of an internationally resurgent Russia, Putin managed to improve his popularity during one of the worst economic crises in recent Russian history. Despite Western-led sanctions that sent Russia's economy into recession in 2014, Putin's approval rating hovered around 80 percent (Levada Center, 2019a).

The spectre of a hostile West was again deployed to bolster support for Putin ahead of the 2018 presidential election. Russian television warned voters that high turnout was the only thing protecting the nation from annihilation by the West. Social media spread rumours of Western government plans to interfere in the election, while state news agencies alleged that more than a dozen countries had attempted cyber-attacks against Russia (Polyankova, 2018). Putin's 2018 presidential rivals were accused of being agents of foreign powers. State media accused communist candidate Pavel Grudinin of stashing \$1 million in a Swiss bank account. The Russian parliament accused those campaigning for an election boycott of receiving funds from foreign governments ('V Sovfede Zayavili,' 2018).

The Russian media further framed the assassination attempt against exiled former Glavnoe Razvedyvatel'noe Upravelnie (GRU) intelligence officer Sergei Skripal on 4 March 2018 to support Putin's narrative of a hostile enemy at the gates. The British government was accused of using the Skripal' case to spread anti-Russian propaganda to shore up its security partnerships ahead of its departure from the EU. Speaking on Russian television 
Pervyy Kanal, political scientist Caroline Galacteros accused the British government of using an attack on its soil to 'return the UK to the European family' ('Odnim iz punktov,' 2018). Speaking on his weekly Vesti Nedeli programme, Dmitry Kiselyov accused the U.S. of plotting the attack to undermine support for Russia's position in Syria (Kiselyov, 2018). In stoking voters' fear and resentment towards hostile Western powers, the Kremlin's propaganda machine achieved its desired results. Turnout in the 2018 election reached a respectable 67.5 percent, with Putin winning 76 percent of votes cast. After the results were announced, Kremlin sources thanked Western leaders for consolidating support behind Putin with their threats. Putin's campaign spokesman Andrei Kondrashov specifically thanked the UK for ensuring 'a level of turnout we weren't hoping to achieve by ourselves' (MacFarquhar, 2018).

Shifting the focus of his discourse from domestic to foreign enemies does not mean that Putin has abandoned populism. Benjamin de Cleen (2017) demonstrates that nationalism is often articulated within populist politics. Nationalism is a discourse constructed around the nation, which is imagined as a limited, sovereign community tied to a certain territory and constructed through opposition to its 'out' groups (Anderson, 1983). Nationalism and populism combine in numerous discursive ways. One combination pits the virtuous people, equated with the nation, against foreign powers and/or multinational institutions that would limit their sovereignty (de Cleen, 2017, p. 353). A good example is the Brexit Party, which claims to be fighting to repatriate popular-national sovereignty from the EU. Putin articulates a similar populist-nationalism that posits the Russian nation as an underdog fighting hegemonic Western powers accused of undermining Russia's national identity and pride.

\subsection{From China to the U.S. as Russia's 'Other'}

Populists' use of 'otherness' to generate support for their leadership is well documented (Mudde, 2007; Ostiguy \& Roberts, 2016). In the case of Russia, the international 'others' against which the nation has been defined and set in opposition has shifted from East to West during Putin's tenure. Given its location between Europe and Asia, for centuries Russian political leaders and intellectuals have debated different visions of Russia's others. Whether or not Russia is part of European civilization is an argument featuring prominently in these debates since tsarist times (Neumann, 1998, p. 167). Starting with Peter the Great, some Russian elites have attempted to define national identity in line with European ideas of enlightenment, constitutionalism, and capitalism. Integration with Europe and imitation of its institutions has been seen by Russia's Westernisers as a path to development (Neumann, 1998, p. 164). In contrast to these would-be-Westernisers, Slavophiles have conceptualised Russia as a unique culture, seeing Europe as a significant other against which Russian civilisation is defined. Both early Slavophiles and Westernisers tended to see Eastern civilisations as barbaric and inferior. But following Russia's humiliation in the Crimean War, some Slavophiles turned towards Asia, praising China's strong state model and India's religiosity (Tsygankov, 2008, p. 767). Slavophile intellectuals began to argue that only by preserving Russia's distinct culture-based on the moral force of orthodoxy and a strong state-could the nation avoid the decadence weakening Europe. In the twentieth century, Bolshevik doctrine similarly perceived Soviet Russia as superior to the 'rotten' capitalist West. Civilisational debates reignited with the collapse of the Soviet Union. President Yeltsin's vision of integration with the West assumed Russia would develop Westernstyle liberal democratic institutions. Yeltsin was opposed by Eurasianists, with roots in the Slavophile tradition, who emphasised Russia's strong ties to Asia and the importance of cultural and geopolitical independence (Tsygankov, 2008, p. 768). On assuming office, Putin embraced a vision of Russia as part of Europe (Putin, 2005). But as Russia's path of development and geopolitical interests have diverged from the West, Putin has pivoted East. Putin has become increasingly critical of many of the West's characteristics, including equal rights for sexual minorities (Makarychev \& Medvedev, 2015). Putin frequently challenges the idea that Western values are universal (Tsygankov, 2008, p. 771). Rather, he maintains that Russia's need for modernisation necessitates an emphasis on political stability and national sovereignty over other values, thus articulating similar civilizational arguments to leaders in China and other Asian states.

When Putin took office in 2000, Russia's media presented China as both an internal and external threat to Russian security. At that time, media reporting on China mainly focused on illegal Chinese immigration as a territorial, economic and cultural danger to Russia's declining population. The media fanned fears that illegal Chinese immigrants were the first wave of China's expansion into Russia's Far East (Hille, 2016). Similarly, Chinese traders in Moscow's markets were accused of undermining local businesses by trading in counterfeit goods (Hutchings \& Tolz, 2015). But for the past decade, as Russia's economic interdependence with China has accelerated, the Russian media has emphasized cooperation between Beijing and Moscow, playing down areas of discord.

Russian television builds a narrative of friendship between China and Russia with frequent references to bilateral summits, joint economic projects, cultural exchanges, and to united action within international institutions such as the United Nations Security Council (UNSC)-often to counter what is presented as the destructive dominance of the U.S. In recent months, for example, Russian television has reported on joint efforts to tackle transnational terrorism ('Bor'ba s terrorizmom,' 2019); booming bilateral trade that in 2019 exceeded $\$ 100$ billion ('Vladimir Putin held Kremlin talks 
with Xi Jinping,' 2019); and Chinese military participation in Russian-led war games ('Vladimir Putin pribyl,' 2019). China's support for Russia at the UN during a debate on Syria also featured prominently on Russian television news ('Na zasedanii Sovbeza,' 2019). The media's reframing of Sino-Russian relations appears to have influenced Russian public opinion of China. A 2006 survey found that 41 percent of Russians thought China was a threat to Russia's interests, while 36 percent believed it was not a threat. But by 2014 , only 19 percent saw China as a threat, while a majority 57 percent felt the opposite (Public Opinion Foundation [POF], 2014). In a June 2017 survey, 62 percent of Russians named China as Russia's closest ally (POF, 2017).

As framing of China has become more positive, Russian media reporting on the U.S. has followed the opposite trajectory. Media framing of the U.S. during Putin's presidency can be divided into several phases. Putin came to office believing Russia's international status would be best enhanced through integration with the West. To pursue his strategy, Putin successfully wooed U.S. President George W. Bush, who famously claimed to have looked into his Russian counterpart's soul and found him straightforward and trustworthy (Perlez, 2001). The Russian media used his relationship with Bush to herald Putin's growing global stature ('Tretiy den' itogi', 2001). The 2003 U.S. invasion of Iraq, however, soured Putin's budding bromance with Bush ('Gunitsky \& Tsygankov,' 2018). Russia's media no longer presented the U.S. president as a potential partner, but as an aggressive militarist with scant regard for international law or national sovereignty ('Dzhordzh Bush i Toni Bler,' 2005).

Although from the beginning of the Iraq war onwards, Russia's media often took a hostile view of Washington's actions-for example, the deployment of American missiles in Poland in 2008-the majority of reporting on the U.S. was surprisingly matter-of-fact ('Pol'sha gotova,' 2008). Negative framing of the U.S. ebbed and flowed as the context of bilateral relations was shaped by events (Tsygankov, 2010). Anti-U.S. rhetoric only became a persistent feature of Russian news after Washington led efforts to sanction Russia over its annexation of Crimea in March 2014 (Tolz \& Teper, 2018). Events in Ukraine were systematically framed as a Washington plot to prevent Russia from taking its rightful place on the world stage (Kiselyov, 2014). Since then, U.S.-Russia relations have been framed as an existential battle for survival (Gaufman, 2017, p. 3). Personal attacks against President Obama and other prominent U.S. policymakers also became more common in Russia's media from 2014. In some quarters, anti-Obama propaganda included racist slurs, conduct not usually seen outside wartime (Dobriansky, 2016). Anti-U.S. narratives in the Russian media appear to have influenced Russian public attitudes. In June 2012, 53 percent of Russians saw bilateral relations with the U.S. as good, while only 17 percent thought they were bad. In June 2014, 64 percent described the relationship as bad, while just 25 percent said it was good (POF, 2018). By mid-2014 the U.S. was seen as the least friendly country towards Russia, even more hostile than Ukraine (POF, 2017).

It was in the context of deteriorating U.S.-Russian relations that Donald Trump emerged as the Republican presidential candidate in 2016. Trump's campaign rhetoric echoed many of the Kremlin's criticisms of Obama's policies. This, along with his praise for President Putin, guaranteed Trump frequent favourable coverage on Russian television. Trump's surprise victory, however, presented a conundrum for Russia's media. Coverage of the president-elect immediately became more negative, as Kremlin spin-doctors tried to lower high expectations of the improved bilateral relations that they had encouraged during the campaign. Russian television began to cover anti-Trump protests that it had previously ignored. Attention also focused on Trump's business failures, political inexperience and sexism, all downplayed during the campaign (Burrett, 2018). Trump's intention to 'get along with Russia,' stated during the presidential debates, was always going to be tempered by his pledges to uphold U.S. military and economic supremacy (Sakwa, 2017). In April 2018, for example, U.S. airstrikes on Damascus, in response to chemical attacks by forces loyal to the Syrian government, were widely condemned on Russian television. In a two-hour special broadcast of Rossiya's 60 Minutes, the U.S. and its allies were accused of faking news of the chemical attack (Lowe, 2018).

The Russian media's intensifying onslaught against the U.S. is motivated by Putin's domestic political needs as well as by tensions with Washington over Ukraine, Syria, and other issues. Anti-U.S. populism is an important component of Putin's efforts to mobilize domestic support for his leadership against a backdrop of economic crisis caused by Western sanctions and rampant domestic corruption. In these precarious circumstances, Putin has based his appeal on promises to vanquish Russia's foreign foes, chief among them, the U.S.

\section{Is Putin's Populism Durable?}

Soon after winning a fourth presidential term in March 2018, Putin's popularity began to decline. For four years following Russia's annexation of Crimea in March 2014, Putin's approval rating averaged above 80 percent. But for the past two years, it has hovered closer to 65 percent (Levada Center, 2019a). More worryingly for Putin, a 2017 survey found that more than two-thirds of Russians held him entirely or significantly responsible for high levels of corruption among state officials (Levada Center, 2017). Putin's long tenure at the top is eroding his ability to brand himself a populist. Russians are growing tired of his nationalist populism and overseas adventurism. Initially, Putin's annexation of Crimea boosted approval of his leadership, as for the first time since the collapse of the Soviet Union, Russians felt like they were a superpower again (Volkov, 2015). Although the Russian 
media dutifully fed these feelings of national grandeur, over time, the 'Crimea effect' on Putin's support levels has waned. Domestic issues are the main concerns of the majority of Russians, who would like Putin to focus more of his attention on problems at home than on wars abroad (Levada Center, 2018a). The Russian government's 2018 plan to reform pensions was almost universally opposed, sparking protests in cities across Russia. In August 2019, Moscow witnessed its largest anti-government protests in more than six years, in response to a ban on many opposition candidates from running in city council elections (Roth, 2019). Almost half of Russians believed that the ban occurred because Putin's government was afraid to face an open competition. Only 25 percent accepted the president's nationalist line that Western interference was the main cause of the protests (Levada Center, 2019b). In the event, progovernment candidates suffered heavy election losses, seeing their share of seats on the 45 -member council slashed from 40 to 25 (Bennetts, 2019).

Putin's preferred candidates were the victims of a well-orchestrated online campaign encouraging tactical voting by opposition leader and anti-corruption crusader Alexei Navalny, who was one of those barred from standing for election. In exposing corruption within the state bureaucracy, Navalny is playing Putin at his own game, basing his appeal on populist issues that matter to ordinary Russians (Pertsev, 2017). And Navalny is not the only populist figure seeking to claim Putin's mantle. In 2018, Russia's Communist Party elected a new charismatic leader, businessman Pavel Grudinin. Grudinin is a popular Internet personality, where his videos promising an end to corruption and a better life for ordinary Russians regularly draw 800,000 views (Pertsev, 2018). As Putin's populist messages become increasingly old and tarnished, the availability of new populist alternatives like Grudinin and Navalny may further syphon support from the president.

Putin's tight control of the Russian media has helped him retain his populist image, despite his many years in power. But growing Internet penetration in Russia provides citizens with access to alternative information to that presented by state-controlled television, still the preferred news source for the majority of Russians (Levada Center, 2018b). As of 2018, 80.6 percent of Russians had Internet access (Internet Live Stats, 2019). Those taking part or supporting the 2019 Moscow election protests were more likely to get their news online than from other sources (Levada Center, 2019b). As he loses control over the information environment, Putin is also losing his ability to control his image and the public agenda.

\section{Conclusion}

This article has argued that although there are populist elements to Vladimir Putin's approach to mobilising support for his leadership, to define him purely as a populist is not entirely accurate. Putin is more populist in his rhetoric than in his ideology or style of governance, conforming most closely to discursive definitions of populism. As his presidency has progressed, Putin's populist discourse has developed increasingly nationalist overtones. Today, 20 years after he first became president, Putin's nationalist-populist narratives aim to maintain a narrow, vertical power structure that discourages public participation in politics. Although Putin came to power by neutralising the influence of Yeltsin-era oligarchs, a new breed of politically-connected tycoons have taken their place (Foy, 2019). In 2020, Russia's kleptocracy is alive and well. A dwindling number of Russians now see Putin in populist terms as the people's champion against a corrupt elite. Putin's relationship with Russian voters is more transactional than emotional, as seen by the rapid evaporation of support for the president when his administration sought to introduce unpopular social welfare reforms. Voters were willing to overlook the inconsistencies between Putin's populist rhetoric and elitebased rule while the economy boomed, and his policies restored domestic stability and international prestige. But the arrival of tech savvy alternatives to Putin, with their own populist messages more suited to the times, is eroding support for the president. State-controlled television, which maintains Putin's heroic 'man of the people' image, is losing audiences to online news. Growing internet access aided the campaign for tactical voting against Putin's preferred candidates in Moscow council elections in September 2019. In the past, Putin succeeded in reinventing his populism by refocusing public anger from domestic economic to international political elites, especially towards the hegemonic influence of the U.S. But today, a growing number of Russians see Putin's foreign policy as an obstacle to Russia's development. Western sanctions over Crimea and the ongoing war in Eastern Ukraine are adversely affecting the economy. After more than five years of sanctions, money is tight. The Kremlin can no longer keep voters on board with cheap mortgages, wage rises, and public sector spending. Under these conditions it is unlikely that disseminating the same anti-U.S. nationalist populism will help Putin recover support. Putin is now the establishment figure against which other Russian nationalist populists make their claims. Endemic corruption and economic inequality fuel Russians' appetite for populist leadership. If Putin isn't able to satisfy populist demands, Russian voters will increasingly turn to others claiming they can.

\section{Acknowledgments}

I am grateful to Sunny Gladish for her research support for this article.

\section{Conflict of Interests}

The author declares no conflict of interests. 


\section{References}

Albertazzi, D., \& McDonnell, D. (2008). Twenty-first century populism: The spectre of Western European democracy. Basingstoke: Palgrave Macmillan.

Anderson, B. (1983). Imagined communities: Reflections on the origins and spread of nationalism. London: Verso.

Baunov, A. (2017). Going to the people-and back again: The changing shape of the Russian regime. Carnegie Moscow Center. Retrieved from https://carnegie.ru/ 2017/01/16/going-to-people-and-back-againchanging-shape-of-russian-regime-pub-67691

Bennetts, M. (2019, September 9). Pro-Putin candidates suffer losses in Moscow elections. The Guardian. Retrieved from https://www.theguardian.com/world/ 2019/sep/09/putin-party-losses-moscow-elections

Bor'ba $s$ terrorizmom $v$ tsentre vnimaniya glav parlamentov Rossii, Kitaya, Turtsii, Pakistana i Afganistana [Fight against terrorism focus of parliamentary heads of Russia, China, Turkey, Pakistan and Afghanistan]. (2019, October 12). Vremya. Retrieved from https://www.1tv.ru/news/2019-10-12/373864borba_s_terrorizmom_v_tsentre_vnimaniya_glav_ parlamentov_rossii_kitaya_turtsii_pakistana_i_ afganistana

Burrett, T. (2011). Television and presidential power in Putin's Russia. London: Routledge.

Burrett, T. (2018). Russian state television coverage of the 2016 U.S. presidential election. Demokratizatsiya, 26(3), 287-320.

Burrett, T. (2019). Evaluating Putin's propaganda performance 2000-2018: Stagecraft as statecraft. In P. Baines, N. O'Shaughnessy, \& N. Snow (Eds.), Sage handbook of propaganda (pp. 492-509). London: Sage.

Conaghan, C., \& de la Torre, C. (2008). The permanent campaign of Rafael Correa: Making Ecuador's plebiscitary presidency. The International Journal of Press/Politics, 13(3), 267-284.

de Cleen, B. (2017). Populism and nationalism. In C. Rovira Kaltwasser, P. Taggart, P. Ochoa Esperjo, \& P. Ostiguy (Eds.), The Oxford handbook of the populism (pp. 341-362). Oxford: Oxford University Press.

de la Torre, C. (2007). The resurgence of radical populism in Latin America. Constellations, 14(3), 384-397.

Dobriansky, P. (2016, January 4). Putin's anti-Obama propaganda is ugly and desperate. The Washington Post. Retrieved from https://www.washingtonpost.com/ opinions/putins-anti-obama-propaganda-is-uglyand-desperate/2016/01/04/57647c48-b0c4-11e5b820-eea4d64be2a1_story.html

Dougherty, J. (2015, December 26). Trash talk. CNN. Retrieved from https://edition.cnn.com/2015/12/25/ europe/vladimir-putin-bad-language/index.html

Dzhordzh Bush i Toni Bler dolzhny predstat' pered mezhdunarodnym sudom za vtorzheniye $v$ Irak [George W. Bush and Tony Blair must appear before international court over invasion of Iraq]. (2005, December 8). Vremya. Retrieved from https://www.1tv.ru/news/ 2005-12-08/227535-dzhordzh_bush_i_toni_bler_ dolzhny_predstat_pered_mezhdunarodnym_ sudom_za_vtorzhenie_v_irak

Elder, M. (2013, March 27). Vladimir Putin's crackdown on NGOs is return to rule by fear. The Guardian. Retrieved from https://www.theguardian.com/world/ 2013/mar/27/vladimir-putin-crackdown-ngo-russia

Ferris, E. (2019, August 6). There's more to Russia than Putin. Foreign Policy. Retrieved from https:// foreignpolicy.com/2019/08/06/theres-more-torussia-than-putin

Fieschi, C. (2019). Populocracy. Newcastle: Agenda Publishing.

Foy, H. (2019, September 25). The Russian oligarchs are gone. Long may they prosper! The Financial Times. Retrieved from https://www.ft.com/content/ 8fbcf652-9c10-11e9-9c06-a4640c9feebb

Gaufman, E. (2017). Security threats and public perceptions: Digital Russia and the Ukraine crisis. Basingstoke: Palgrave.

Goldman, M. (2004). Putin and the oligarchs. Foreign Affairs, 83(6), 33-44.

Gunitsky, S., \& Tsygankov, A. (2018). The Wilsonian bias in the study of Russian foreign policy. Problems of Post-Communism, 65(6), 385-393.

Hansen, A., Cottle, S., Negrine, R., \& Newbold, C. (1998). Mass communication research methods. London: Macmillan.

Hechter, M. (2001). Containing nationalism. Oxford: Oxford University Press.

Hille, K. (2016, February 5). Russia and China: Friends with benefits. The Financial Times. Retrieved from https://www.ft.com/content/f8959924-cab6-11e5a8ef-ea66e967dd44

Hille, K., \& Foy, H. (2018, March 15). The Russian election and the rise of Putin's young technocrats. The Financial Times. Retrieved from https://www.ft.com/ content/1fb872b8-26b0-11e8-b27e-cc62a39d57a0

Humphreys, B., \& Bivens, M. (2000, February 10). Chubais, other oligarchs under fire. Moscow Times.

Huskey, E. (1999). Presidential power in Russia. New York, NY: M. E. Sharpe.

Hutchings, S., \& Tolz, V. (2015). Nation, ethnicity and race on Russian television. London: Routledge.

Internet Live Stats. (2019). Russia Internet users. Internet Live Stats. Retrieved from http://www. internetlivestats.com/internet-users/russia

Kiselyov, D. (2014, March 2). 'Vesti Nedeli' 02.03.2014 [News of the Week] [Television news broadcast]. Moscow: Rossiya. Retrieved from https://russia. tv/video/show/brand_id/5206/episode_id/971177/ video_id/976432

Kiselyov, D. (2018, March 18). 'Vesti Nedeli' c Dmitriem Kiselyovem 18.03.2018 [News of the Week] [Television news broadcast]. Moscow: Rossiya. Retrieved from https://youtube.com/watch?v=26TSeXYwHBQ 
Krastev, I. (2007). Russia as the 'other Europe.' Russia in Global Affairs, 5(4), 66-78.

Krastev, I., \& Holmes, S. (2012). An autopsy of managed democracy. Journal of Democracy, 23(3), 33-45.

Lambroschini, S. (2000, March 3). Russia: Putin's one theme Is firmness. RFE/RL. Retrieved from https:// www.rferl.org/a/1093560.html

Laruelle, M. (2009). Russian nationalism and the national reassertion of Russia. London: Routledge.

Laruelle, M. (2013). Conservatism as the Kremlin's new toolkit. Russian Analytical Digest, 138(8), 2-4.

Latynina, Y. (2003, February 24). Khodoki u Putina [Putin's move]. Novaya Gazeta.

Levada Center. (2012, November 28). Natsionalnaya politika-i otnoshenie $k$ migrantam [Nationalist politics and attitudes toward immigration]. Levada Center. Retrieved from http://www.levada.ru/28-112012/natsionalnaya-politika-i-otnoshenie-kmigrantam

Levada Center. (2017). Institutsinal'naya korruptsiya i lichyy opyt [Personal experiences of institutional corruption]. Levada Center. Retrieved from http:// www.levada.ru/2017/03/28/institutsionalnayakorruptsiya-i-lichnyj-opyt

Levada Center. (2018a). Sotsiologiya vyborov [Sociology of elections]. Levada Center. Retrieved from https:// www.levada.ru/2018/03/29/sotsiologiya-vyborov-2

Levada Center. (2018b). Channels of information. Levada Center. Retrieved from https://www.levada.ru/ en/2018/10/12/channels-of-information

Levada Center. (2019a). Approval ratings. Levada Center. Retrieved from https://www.levada.ru/en/2019/04/ 11/approval-ratings-7

Levada Center. (2019b). Protestnaya aktivnost [Protest activity]. Levada Center. Retrieved from https:// www.levada.ru/2019/09/03/protestnaya-aktivnost-5

Lowe, T. (2018, April 15). 'Complete nonsense': How Russian media covered the air strikes in Syria. $A B C$ News. Retrieved from https://www.abc.net.au/ news/2018-04-15/syria:-heres-how-the-russianmedia-covered-the-air-strike/9660256

MacFarquhar, N. (2018, March 19). Russia credits the West for Putin's big victory. The New York Times. Retrieved from https://www.nytimes.com/2018/03/ 19/world/europe/russia-putin-vote-president.html

Madrid, R. (2008). The rise of ethnopopulism in Latin America. World Politics, 60(3), 475-508.

Mair, P. (2002). Populist vs party democracy. In Y. Meny \& Y. Surel (Eds.), Democracies and the populist challenge (pp. 81-98). Basingstoke: Palgrave.

Makarychev, A., \& Medvedev, S. (2015). Biopolitics and power in Putin's Russia. Problems of PostCommunism, 62(1), 45-54.

Morelock, J. (2018). Critical theory and authoritarian populism. London: University of Westminster Press.

Mudde, C. (2007). Populist radical right parties in Europe. Cambridge: Cambridge University Press.

Mudde, C., \& Rovira Kaltwasser, C. (2012). Populism in Eu- rope and the Americas: Threat or corrective to democracy? Cambridge: Cambridge University Press.

Mudde, C., \& Rovira Kaltwasster, C. (2014). Populism and political leadership. In R. A. Rhodes \& P. T. Hart (Eds.), The Oxford handbook of political leadership (pp. 376-388). Oxford: Oxford University Press.

Müller, J. (2016). What is populism? Philadelphia, PA: University of Pennsylvania Press.

Müller, J. (2017). Populism and constitutionalism. In C. Rovira Kaltwasser, P. Taggart, P. Ochoa Esperjo, \& P. Ostiguy (Eds.), The Oxford handbook of the populism (pp. 590-606). Oxford: Oxford University Press.

Myers, S. L. (2005, January 16). Putin reforms greeted by street protests. The New York Times. Retrieved from https://www.nytimes.com/2005/01/16/world/ europe/putin-reforms-greeted-by-streetprotests.html

Naryshkina, A. (2004, January 22). 'Lish' by ne bylo bogatyk [If only there were no rich]. Izvestia. Retrieved from https://iz.ru/news/286062

$\mathrm{Na}$ zasedanii Sovbeza OON po situatsii $v$ Idlibe ne udalos' prinyat' ni odin iz variantov rezolyutsii [At the UNSC meeting on Idlib none of the resolutions were adopted]. (2019, September 20). Vremya. Retrieved from https://www.1tv.ru/news/2019-09-20/ 372589-na_zasedanii_sovbeza_oon_po_situatsii_ v_idlibe_ne_udalos_prinyat_ni_odin_iz_variantov_ rezolyutsii

Neumann, I. (1998). Uses of others: The East in European identity. Minneapolis, MN: University of Minnesota Press.

O'Brien, T. (2015). Populism, protest and democracy in the twenty-first century. Contemporary Social Science, 10(4), 337-348.

Odnim iz punktov povestki sammita Yevrosoyuza stalo delo otravlennogo $v$ Velikobritanii Sergeya Skripalya [Poisoning of Sergei Skripal in UK on EU summit agenda]. (2018, March 25). Voskrenoya Vremya. Retrieved from https://www.1tv.ru/news/ 2018-03-25/342960-odnim_iz_punktov_povestki_ sammita_evrosoyuza_stalo_delo_otravlennogo_v_ velikobritanii_sergeya_skripalya

Ostiguy, P. (2017). Populism: A socio-cultural approach. In C. Rovira Kaltwasser, P. Taggart, P. Ochoa Esperjo, \& P. Ostiguy (Eds.), The Oxford handbook of the populism (pp. 73-97). Oxford: Oxford University Press.

Ostiguy, P., \& Roberts, K. M. (2016). Putting Trump in comparative perspective: Populism and the politicization of the sociocultural low. Brown Journal of World Affairs, 23(1), 25-50.

Pappas, T. (2019). Populists in power. Journal of Democracy, 30(2), 70-84.

Perlez, J. (2001, June 18). Cordial rivals: How Bush and Putin became friends. The New York Times. Retrieved from https://www.nytimes.com/2001/ 06/18/world/cordial-rivals-how-bush-and-putinbecame-friends.html

Pertsev, A. (2017, August 28). Alexei Navalny's 
techno-populism. Carnegie Endowment for International Peace. Retrieved from https://carnegie.ru/ commentary/72913

Pertsev, A. (2018). The Grudinin effect: A populist shakes up Russian politics. Carnegie Endowment for International Peace. Retrieved from https://carnegie.ru/ commentary/75371

Petrova, A. (2001). K situatsii vokrug NTV [The situation around NTV]. Public Opinion Foundation. Retrieved from https://bd.fom.ru/report/map/of011403

Petrova, A. (2003, July 17). Rossiyane o krupnom biznese [Russians on big business]. Public Opinion Foundation. Retrieved from https://bd.fom.ru/report/cat/ business/ec_bus/businessman/of032708

Pol'sha gotova razmestit' u sebya Amerikanskiye rakety [Poland ready to host U.S. missiles]. (2008, February 2). Vremya. Retrieved from https:// www.1tv.ru/news/2008-02-02/196336-polsha_ gotova_razmestit_u_sebya_amerikanskie_rakety

Polyankova, A. (2018, March 18). How Russia meddled in its own elections. The Atlantic. Retrieved from https://www.theatlantic.com/international/archive/ 2018/03/russia-putin-election-disinformationtroll/555878

Public Opinion Foundation. (2014). Otnosheniya mezhdu Rossiyey i Kitayem [Russia-China relations]. Public Opinion Foundation. Retrieved from https://fom.ru/ Mir/11460

Public Opinion Foundation. (2017). O Rossii i stranakh mira [Russia and the countries of the world]. Public Opinion Foundation. Retrieved from https://fom.ru/ Mir/13624

Public Opinion Foundation. (2018). Ob otnosheniyakh Ameriki i Rossii [U.S.-Russia relations]. Public Opinion Foundation. Retrieved from https://fom.ru/Mir/ 14143

Putin, V. (2000a, February 25). Open letter to voters. Kremlin.ru. Retrieved from http://en.kremlin.ru/ events/president/transcripts/24144

Putin, V. (2000b, August 23). Speech of Vladimir Putin. Vesti.

Putin, V. (2005, April 25). Poslaniye Federal'nomu Sobraniyu Rossiyskoy Federatsii [Message to the Federal Assembly of the Russian Federation]. Kremlin.ru. Retrieved from http://kremlin.ru/events/president/ transcripts/22931

Reddaway, P. (2001). Will Putin be able to consolidate power? Post-Soviet Affairs, 17(1), 23-44.

Roth, A. (2019, August 11). Thousands march in Moscow demanding open city elections. The Guardian. Retrieved from https://www.theguardian.com/world/ 2019/aug/10/thousands-march-in-moscowdisqualification-city-elections

Ruble, B., Koehn, J., \& Popson, N. (2001). Fragmented space in the Russian Federation. London: John Hopkins University Press.

Russian Public Opinion Research Center. (1999, August). Presidential voting Intentions. Russia Votes. Re- trieved from http://www.russiavotes.org

Sakwa, R. (2012). Sovereignty and democracy: Constructions and contradictions in Russia and beyond. Region: Regional Studies of Russia, Eastern Europe, and Central Asia, 1(1), 23-17.

Sakwa, R. (2017). U.S.-Russian relations in the Trump era. Insight Turkey, 19(4), 13-27.

Schuler, C. (2015). Performing democracy Putin-style. The Drama Review, 59(1), 136-159.

Smirnov, K. (2003, November 10). I vse posmotreli na Kas'yanova [All eyes turn to Kasyanov]. Kommersant Vlast. Retrieved from https://www.kommersant.ru/ doc/426341

Sperling, V. (2016). Putin's macho personality cult. Communist and Post-Communist Studies, 49(1), 13-23.

Strauss, J. (2003, November 8). Putin's language is becoming the talk of the vulgar. The Telegraph. Retrieved from https://www.telegraph.co.uk/news/ uknews/1446241/Putins-language-is-becomingthe-talk-of-the-vulgar.html

Tavernise, S. (2003, November 3). Russia is mostly unmoved by the troubles of its tycoons. The New York Times. Retrieved from https://www.nytimes.com/ 2003/11/03/world/russia-is-mostly-unmoved-bythe-troubles-of-its-tycoons.html

Teague, E. (2014). Russia's return to the direct election of governors. Regions, 3(1), 37-57.

Thornhill, J. (2000, February 28). Challengers to the oligarchs. The Financial Times.

Tolz, V. (2017). From a threatening 'Muslim migrant' back to the conspiring 'West.' Nationalities Papers, 45(5), 742-757.

Tolz, V., \& Harding, S.-A. (2015). From 'compatriots' to 'aliens': The changing coverage of migration on Russian television. The Russian Review, 74(3), 452-477.

Tolz, V., \& Teper, Y. (2018). Broadcasting agitainment: A new media strategy of Putin's third presidency. Post-Soviet Affairs, 34(4), 213-227. Tretiy den' itogi vstrechi prezidentov Rossii i SSHA ostayutsya odnoy iz glavnykh mezhdunarodnykh tem [For the third day U.S.-Russian leaders' summit is a key topic]. (2001, June 19). Vremya. Retrieved from https://www.1tv.ru/news/2001-06-19/278909tretiy_den_itogi_vstrechi_prezidentov_rossii_i_ ssha_ostayutsya_odnoy_iz_glavnyh_. mezhdunarodnyh_tem

Tsygankov, A. (2008). Self and other in international relations theory: Learning from Russian civilization. International Studies Review, 10(4), 762-775.

Tsygankov, A. (2010). Russia's foreign policy: Change and continuity in national identity. Boulder, CO: Rowman $\&$ Littlefield.

V Kremle sostoyalis' peregovory Vladimira Putina s Si TSzin'pinom [Vladimir Putin held Kremlin talks with Xi Jinping]. (2019, June 5). Vremya. Retrieved from https://www.1tv.ru/news/2019-06-05/366418v_kremle_sostoyalis_peregovory_vladimira_putina_ s_si_tszinpinom_kotoryy_nahoditsya_v_rossii_s_ 
gosudarstvennym_vizitom

Vladimir Putin pribyl v Orenburgskuyu oblast,' gde proydet osnovnoy etap ucheniy 'Tsentr-2019' [Putin arrives in Orenburg where Center-2019 exercises will take place]. (2019, September 20). Vremya. Retrieved from https://www.1tv.ru/news/2019-09-20/ 372596-v_orenburgskoy_oblasti_vladimir_putin_ lichno_nablyudal_za_kulminatsiey_masshtabnyh_ ucheniy_tsentr_2019

Volkov, D. (2015). How authentic is Putin's approval rating? Carnegie Endowment for International Peace. Retrieved from https://carnegie.ru/commentary/ 60849

Volkov, D. (2018). 'No trust': What Russians think about pensions reform. Carnegie Endowment for Inter- national Peace. Retrieved from https://carnegie.ru/ commentary/77015

V Sovfede Zayavili o roste finansirovaniya vnesistemnoy oppozitsii iz-za rubezha [Federal Council announces growing funding of opposition groups from abroad]. (2018, March 5). Interfax. Retrieved from http:// www.interfax.ru/elections2018/602413

Weber, M. (1978). Economy and society. Berkeley, CA: University of California Press.

Williamson, V., Skocpol, T., \& Coggin, J. (2011). The Tea Party and the remaking of republican conservatism. Perspectives on Politics, 9(1), 25-43.

Yasmann, V. (2007). Russia: Putin comes on strong. RFE/RL. Retrieved from https://www.rferl.org/a/ 1074659/html

\section{About the Author}

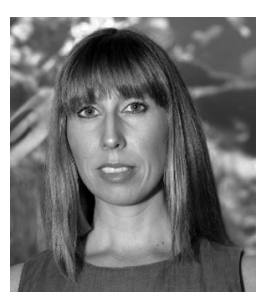

Tina Burrett is Associate Professor of Political Science at Sophia University, Japan. She publishes on politics and media freedom, especially in Russia, Japan, and Myanmar. Her recent publications on Russia include 'Evaluating Putin's Propaganda Performance 2000-2018' Sage Propaganda Handbook (2019), and 'Russian State Television Coverage of the 2016 US Presidential Election,' Demokratizatsiya (2018). She is also author of Press Freedom in Contemporary Asia (Routledge 2019, with Jeff Kingston). She has worked in the UK, Japanese, Canadian, and European Parliaments and received a PhD in Political Science from Cambridge University in 2007. 